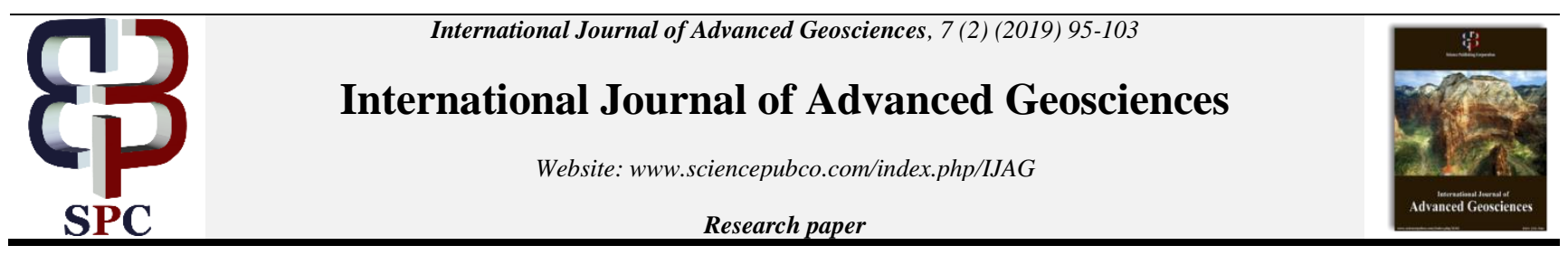

\title{
The field geology and petrography of the kofayi younger granite complex, central Nigeria
}

\author{
Aga T ${ }^{1 *}$, Haruna A. I. ${ }^{2}$ \\ ${ }^{1}$ Department of Geology, University of Jos, Jos, Nigeria \\ ${ }^{2}$ Department of Applied Geology, Abubakar Tafawa Balewa University, Bauchi, Nigeria \\ *Corresponding author E-mail:
}

\begin{abstract}
The Kofayi Younger Granite Complex is one of the several anorogenic alkaline Younger Granite Complexes that is located approximately 45 kilometres north east of Jos, Nigeria. The complex is found to comprise of felsic rocks like; biotite-granites, biotite microgranites and granodiorites. They are also found to be associated with mafic rocks like diorites which, at some portions have formed hybrid rocks. Quartzfeldspar- granites are the porphyritic rocks that found in the ring complex. The complex intrude the basement rocks of central Nigeria. Structural trends on these rocks suggest that they were controlled by some deep seated structures of the basement. Mineral suite identified include; fayalite, pyroxene, amphibole, k-feldspar, biotite, quartz, iron- oxide and accessory minerals like zircon, apatite, and allanite. Generally, the petrography of these rock samples reveal the presence of a mafic magma which has two pulses (a mafic and felsic pulse) of injection.
\end{abstract}

Keywords: Kofayi; Granite; Geology; Petrography; Structures.

\section{Introduction}

The Younger Granites Ring Complexes are located in the southern part of a $200 \mathrm{~km}$ wide zone, along the $9^{\text {th }}$ meridian and extending 1250 $\mathrm{km}$ from Andrar Bous in northern Niger to Afu in the margin of the Benue Trough in Nigeria (Fig.1). The form and general pattern of the ring centres may have been controlled by pre-existing lines of weakness in the Pan African basement (Kinnaird et al, 1985).

The Kofayi Younger Granite Complex is one of the several anorogenic alkaline Younger Granite Complexes in the Nigerian Pan African Basement Complex (Macleod et al, 1971) (Figs 1 and 2). The complex is found associated with gabbroic and doleritic/dioritic enclaves, peralkaline and peraluminous igneous rocks (Plates 1).

In the study of the Nigerian Younger Granites, the Kofayi Complex constitute a significant window to the detailed understanding of the magmatic evolutionary trends and metallogenic characteristics of the Nigerian Younger Granites as a whole. This is because of the prominent occurrence of mafic rocks which may represent the more primitive magma in the Younger Granite Province. At present, the origin of these anorogenic granites in Nigeria is still very intriguing due to inadequate data. This paper attempts to describe the various lithological units within the suite and the petrographic analysis. 


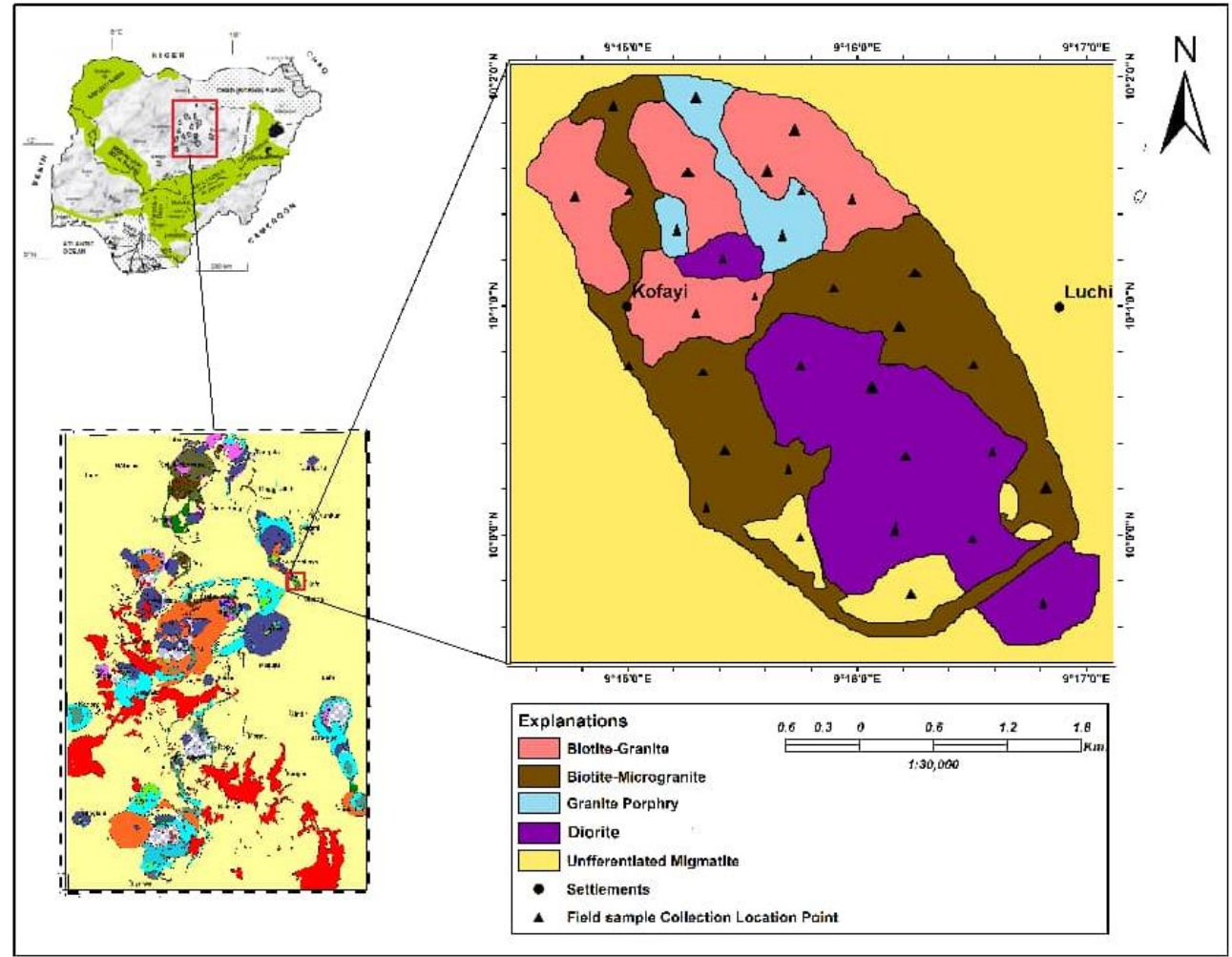

Fig. 1: Top = Geological Map of Nigeria Showing the Location of the Younger Granite Ring Complexes (After Obaje, 2009); Left = Map of Younger Granites Ring Complexes of Nigeria (Modified After Kinnard Et Al, 1985); Centre = Geological Map of Kofayi Younger Granite Complex.

\section{Study area}

The area investigated is the Kofayi Younger Granite complex which can be accessed through Rinjin Gani which lies approximately 45 kilometres north of Jos, Plateau State. The Complex is situated between latitudes $09^{\circ} 08^{\prime} 00^{\prime \prime} \mathrm{N}$ and $10^{\circ} 20^{\prime} 30^{\prime \prime} \mathrm{N}$ and longitudes $9^{\circ} 14^{\prime} 30^{\prime \prime} \mathrm{E}$ and $9^{\circ} 17^{\prime} 30^{\prime \prime E}$ which belong to part of Toro sheet 148 SE. This suite occupies an area of approximately 11.71 square kilometres is oval in shape (Fig. 2). The diorites form the low-lying marshy ground, the biotite-granite and granite porphyry forms the compact hills at the northern end while the biotite-microgranite occurs as low ridges on the central and southern part of the complex (Fig.1).

Kofayi hills trend in a clear NW direction and occupies the central portion of the study area. The peak located within the north central area is over 1053 metres above sea level. River Gaga flows in the SSE direction while river Bilidi takes its source from the Kofayi hills and flow in the NE direction. All the rivers in the study areas are seasonal, display a dendritic drainage pattern and are morphologically controlled. (Figs. $2 \& 3$ ). Generally, the lowlands constitute the basement rocks while the Younger Granite rocks exhibit relatively high relief due to its resistance to weathering.

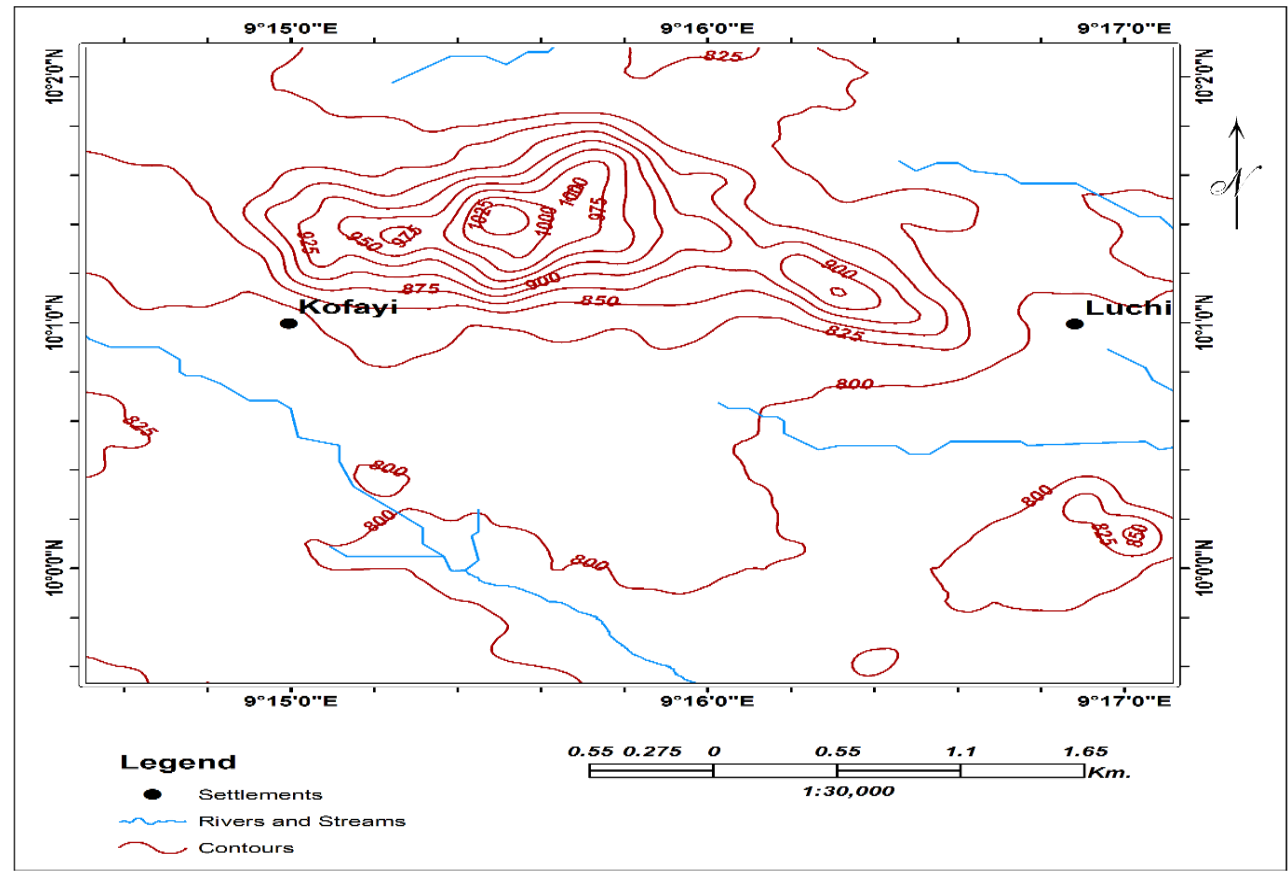

Fig. 2: Physiographic Map of the Kofayi Younger Granite Complex. 


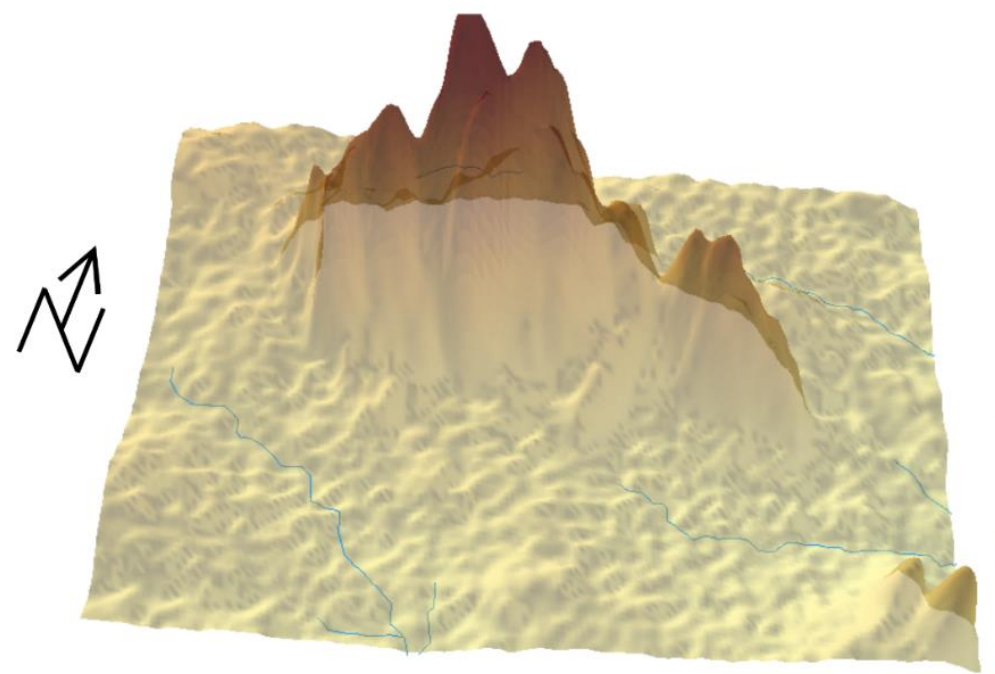

\section{Legend}

\section{$\sim$ Rivers and Streams}

Elevation in Meters

Value

High : 1053

Low : 776

Fig. 3: Digital Elevation Modem (DEM) of the Kofayi Younger Granite Complex.

\section{Petrology}

Table 1: Chemical Composition of the Rocks of the Kofayi Younger Granite Complex

\begin{tabular}{|c|c|c|c|c|c|c|c|c|c|c|c|c|c|c|}
\hline Sample ID & Location & Petrology & $\mathrm{SiO}_{2}$ & $\mathrm{CaO}$ & MgO & $\mathrm{SO}_{3}$ & $\mathrm{~K}_{2} \mathrm{O}$ & $\mathrm{Na}_{2} \mathrm{O}$ & $\mathrm{TiO}_{2}$ & $\mathrm{MnO}$ & $\mathrm{P}_{2} \mathrm{O}_{5}$ & $\mathrm{Fe}_{2} \mathrm{O}_{3}$ & $\mathrm{Al}_{2} \mathrm{O}_{3}$ & $\mathrm{H}_{2} \mathrm{O}^{+}$ \\
\hline AT4 & Kofai & Granite & 72.7 & 1.85 & 0.03 & 0.52 & 4.01 & 0.86 & 0.67 & 0.2 & 0.003 & 3.7 & 12.8 & 1.6 \\
\hline AT17 & Kofai & Granite & 74.61 & 1.06 & 0.03 & 0.48 & 4.86 & 0.43 & 0.74 & 0.061 & 0 & 1.5 & 13.43 & 1.68 \\
\hline AT18 & Kofai & Granite & 73.2 & 0.65 & 0.007 & 0.062 & 5.55 & 1 & 0.66 & 0.039 & 0 & 2.04 & 13 & 2.34 \\
\hline AT22 & Kofai & Granodiorite & 72.7 & 2.5 & 1.89 & 0 & 1.9 & 0.48 & 1.78 & 0.15 & 0 & 3.92 & 12 & 2.08 \\
\hline AT23 & Kofai & Diorite & 56.5 & 6.81 & 3.06 & 0.33 & 1.6 & 0.46 & 4.03 & 0.21 & 0.18 & 12.8 & 10.3 & 2.81 \\
\hline AT26 & Kofai & Granite & 73.43 & 0.3 & 0.04 & 0.003 & 5.09 & 1.06 & 0.5 & 0.024 & 0 & 3.46 & 13.01 & 2.24 \\
\hline AT29 & Kofai & Diorite & 54.4 & 9.9 & 1.02 & 0.77 & 0.98 & 0.07 & 1.94 & 0.26 & 0.06 & 12.3 & 10.3 & 4.58 \\
\hline AT44 & Kofai & Granite & 87.6 & 0.73 & 0.14 & 0.48 & 5 & 1.02 & 0.13 & 0.026 & 0 & 0.44 & 2.43 & 1.02 \\
\hline AT37 & Kofai & Diorite & 58.5 & 4.23 & 9.1 & 0.62 & 2.03 & 0.43 & 2.68 & 0.22 & 0 & 8.06 & 10.5 & 3.05 \\
\hline AT39 & Kofai & Granite & 74 & 1.07 & 0.5 & 0.072 & 5.12 & 1.04 & 0.48 & 0.081 & 0.003 & 1.16 & 13.06 & 2.06 \\
\hline AT51 & Kofai & Granite & 75.06 & 0.38 & 0.007 & 0.23 & 5.85 & 0.76 & 0.16 & 0.028 & 0 & 1.98 & 13 & 1.78 \\
\hline AT60 & Kofai & Granite & 71.01 & 2.04 & 0.5 & 0.17 & 4 & 0.34 & 1.39 & 0.096 & 0 & 3.038 & 12.86 & 2.86 \\
\hline AT62 & Kofai & Granite & 72.48 & 3.25 & 1 & 0.61 & 1.03 & 1.28 & 1.3 & 0.067 & 0.004 & 2.9 & 12.66 & 1.4 \\
\hline AT68 & Kofai & Granite & 75.2 & 0.33 & 0.005 & 0.3 & 6.29 & 0.53 & 0.2 & 0.039 & 0 & 1.05 & 13.46 & 1.4 \\
\hline AT71 & Kofai & Diorite & 54.2 & 7.62 & 0.93 & 0.73 & 1.09 & 0.63 & 2.77 & 0.23 & 0.04 & 16.09 & 11.26 & 3.08 \\
\hline AT 81 & Kofai & Granite & 73.06 & 3.18 & 0.34 & 0.13 & 4.65 & 0.81 & 0.83 & 0.11 & 0 & 4.18 & 12.64 & 2.07 \\
\hline
\end{tabular}

The major composition of sixteen (16) selected rock samples is given in Table 1 above. The results were plotted on the petrological classification plot developed after Middlemost, 1985. The felsic comprising of various peralkaline and peraluminous granites and rhyolites fell in the granite section (Fig. 4) and are quart-rich granitoids (Fig. 5). The mafics which are mainly diorites plotted in the appropriate polygon (Fig.4) and the QAPF diagram suggest that they are rich in akali feldspars.

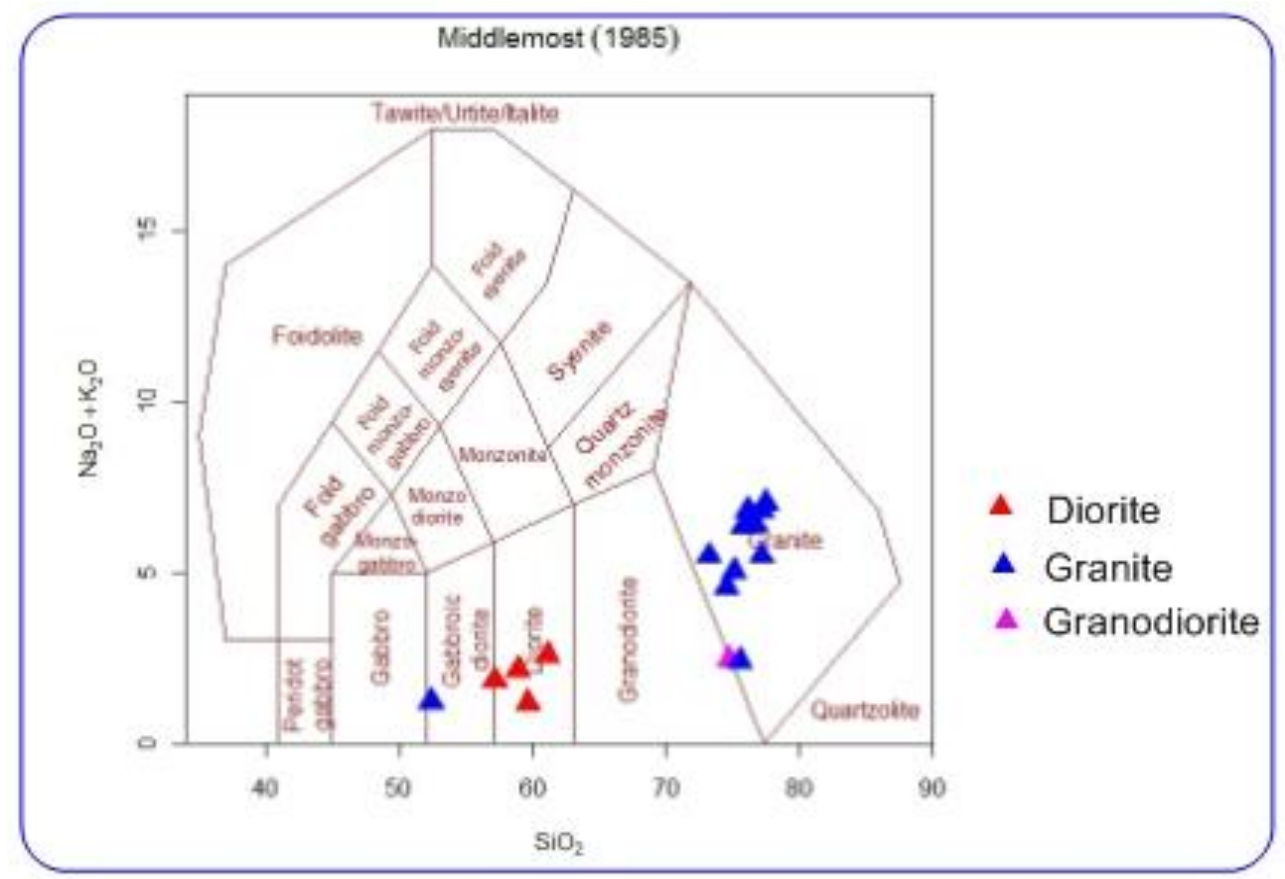

Fig. 4: Rock Classification (After Middlemost, 1985). 


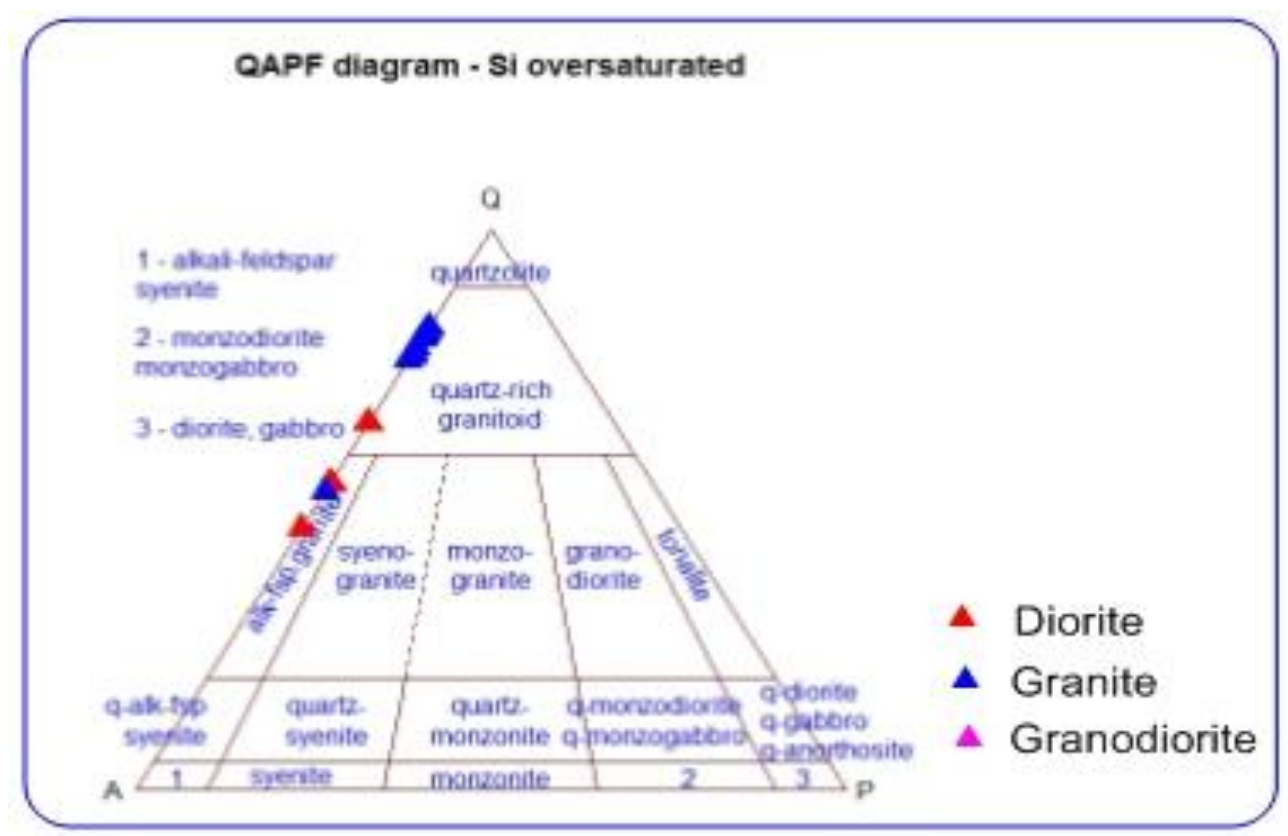

Fig. 5: QAPF - Si Oversaturated Diagram.

\section{Field description}

The description given are generated from field observation during the one month field work in the study area. Attention is paid to the colour, texture of the mafics and felsic rocks in the Kofayi Younger Granite Complex.

\subsection{Diorite and dolerite}

The diorite form the low-lying marshy ground in the central and eastern end of the complex. They occupy approximately $30 \%$ of the study area. The diorites are poorly exposed in the centre of the complex and are largely unveined. They occur as scattered and irregularly shaped plutons around the vicinity of Kufai town. The black sand observed all over the drainage and foot paths of the complex are weathered products from the diorites. The diorites range in texture from coarse to medium-grained.

The dolerite is situated at the eastern margin of the complex where it forms a small outcrop that can be hardly distinguished from the diorites due to gradational contacts. It is dark-grey in colour and fine grained. The hybrid diorite is characterized by its distinct and irregular net-veining by the acid phase (Fig. 6).

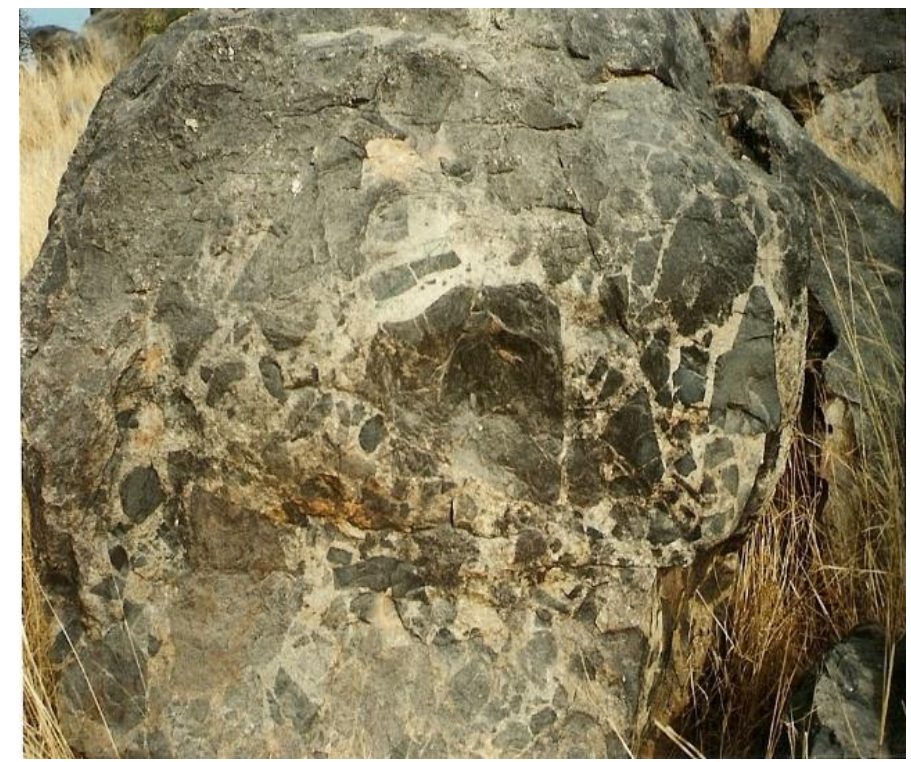

Fig. 6: Dioritic Enclaves at Kofayi. 


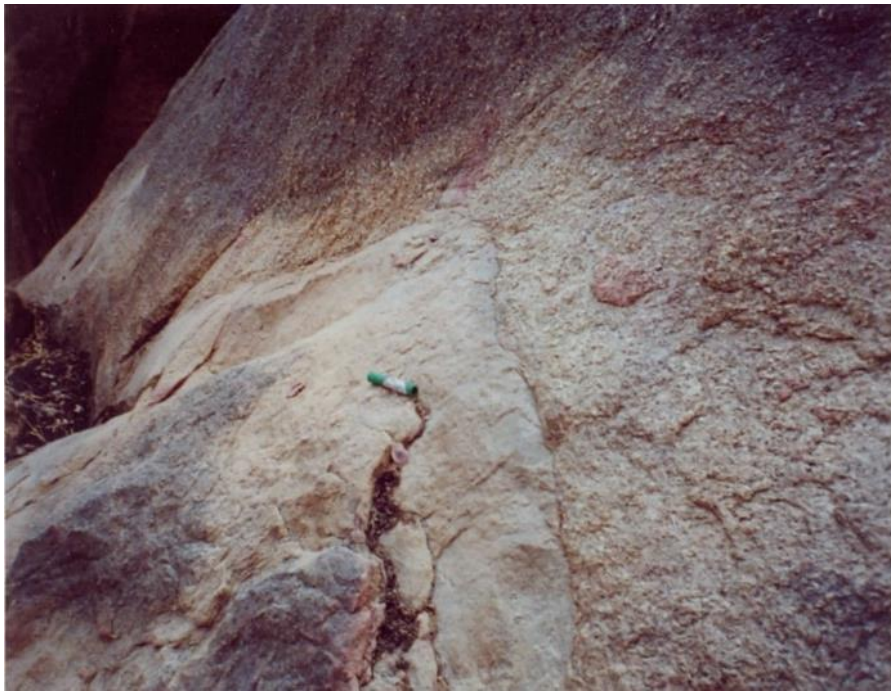

Fig. 7: Aplite Dyke on Biotite Granite.

\subsection{Biotite granite}

This forms much of the highlands in the northwestern part and occupies approximately $25 \%$ of the study area and it is cut by thin sheets of microgranite (Fig. 7). The rock is medium-grained with average grain size of about 2.5 milimetres. The colour of the rock varies from pink to pale yellow. They are commonly found as large circular and crescentic outcrops. They generally display regular open jointing and are intensely weathered in some cases, producing horizontal sheeting.

The nature of the contact between the biotite granite and the other rocks is variable. Often they show a progressive decrease in grain size towards its outer contacts and porphyritic and micro-granite zone appear within a few metres of the contacts.

\subsection{Biotite microgranite}

The biotite microgranite occupies approximately $20 \%$ of the study area and form the peripheral ring-dyke system that mark the outline of the complex. They occur as a single dyke along the southeastern and northern margins. They also occur as near vertical granite dykes and gently dipping sheets. Micro-granite also net-veins the mafic rocks. The rock comprise of a dark and light variety. Both are fine to medium grained and equigranular in texture. The variation in colour is largely due to the content of mafic minerals. The dark variety has a preponderance of biotite.

\subsection{Quartz - feldspar granite porphyry}

The granite porphyry occupies about $15 \%$ of the study area and forms an elongated body about half $(1 / 2)$ kilometres long in the north western part. Some portions form small isolated outcrops. Part of it net-veins the mafic rocks. It is coarse in texture and also porphyritic. The change in colour from light grey to pink is due to oxidation. Consequently, it appears as brownish rather than greenish rock. It has a pitted surface on account of surface weathering leaving the feldspars to stand out profusely.

\section{Structural geology}

The structural features observed in the field of study include joints, dykes and veins. Measurement carried out on them reveal that they display variable trends.

\subsection{Joints}

Fractures that are oriented systematically, with no evidence of relative movement, are called joints. The dominant trend of the joints in the Kofayi Complex is approximately NW-SE with steep to vertical dips (Figs. 9). Joints observed on these Younger Granite complexes are not structurally controlled hence are cooling joints formed as a result of contraction and cooling of the emplaced magma. Also, the uniformity in the trends of the joints suggest that they are syngenetic.

\subsection{Dykes}

A dyke is a sheet-like discordant body within the country rock in which they occur. The dykes in the Kofayi study area are mostly pegmatite, dolerite and aplite dykes (Fig.7). Ring dykes of biotite-microgranite occur in the southern flank of the complex. The dyke is of variable width, generally not less than 5 metres and may locally thicken to produce swell structures. Their contact with the enclosing rocks are usually sharp with some parts in the other flank displaying pegmatite zone.

\subsection{Veins}

Veins are joints that have been filled. In the study area, these joints have been filled by quartz and hence are referred to as quartz veins. The quartz veins are thin, raging in thickness from 0.4 to $0.7 \mathrm{~cm}$ and their lengths vary between 3 and 18 metres. There are also net-veins in the study area. These are network of veins of felsic intrusions injected under high considerable pressure and penetrating a marginal zone 
of the mafic rocks thus forming a meshwork. Reacting between the veining materials and the mafic host rock is common, giving rise to hybrid rocks.

Felsic magmatic intrusion formed the veining material within the mafic rocks of the Kofayi Complex. They are linked at intervals points by cross-connecting veins, the contact of the veins with the mafic rocks are sometimes highly irregular. This is evidence of flow of felsic material marked by preferred trend of feldspar and hornblende. The evidence of the flow indicate that the veins did not form metasomatically and the highly irregular contacts are not such as would be expected if the host rock had been solid when the felsic material was intruded. The thickness of the veins vary between 0.1 and 0.9 metres (Fig. 8). The average dimension of the smaller elliptical vein is 0.13 metres on the minor axis by 0.33 metres on the major axis.

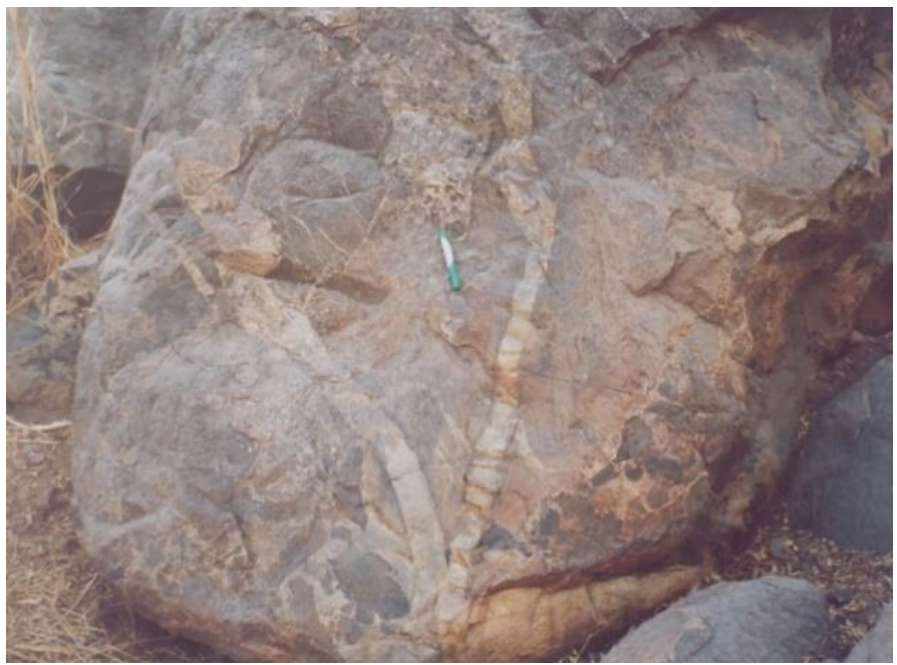

Fig. 8: Quartz Veins in Kofayi.

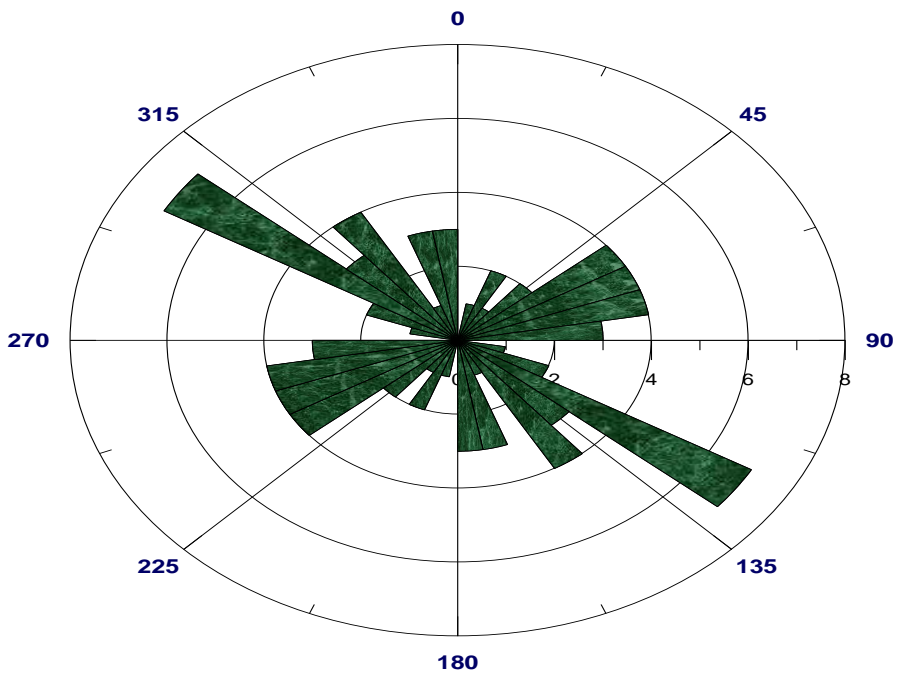

Fig. 9: General Structural Trend.

\subsection{Xenoliths}

A xenolith is a pre-existing rock embedded in a newer (igneous rock). Xenoliths are formed when a rising magma incorporates the preexisting rock. If the pre-existing rock does not melt, it will not be assimilated into the magma and will therefore remain distinct from the new igneous rock that surrounds it. Xenoliths observed in the study areas are mostly mafic in composition and of varying sizes, some up to 1.5 by 2.6 metres. A larger percentage of the xenoliths are formed in the area of net veinings of mafic rocks by felsic materials.

\subsection{Micro-faults}

Micro-faults are faults that occur in a very small scale and they are usually observed as faulting occurring in veins and joints. In the Rishi study area, they were observed on the diorite.

\subsection{Structural interpretation}

In Nigeria, the major structural directions are oriented N-S, NE-SW, NW- SE, NNE-SSE and ENE - WSW, corresponding to the major structural trends in the Basement Complex and direction of alignment of the Younger Granite ring complexes (Rahaman et al, 1988; Turner 1989).

The form and general distribution pattern of the ring centres may have been controlled by these pre-existing lines of weakness in the PanAfrican Basement into which the Younger Granite Complexes were intruded.

In the study area, the following joint directions were mapped, N-S, NE- SW, NW-SE, NNE-SSW and E-W which correspond with the structural trend of the underlying basement. The general structural trend in the study area is shown in Fig. 9. This suggest that these joint 
direction are outward prolongation of deep seated fracture zones that initiate and guided the location of the Younger Granite eruption centres. They followed these weak zones during eruption in the Jurassic (165 $\pm 25 \mathrm{ma})$.

\section{Petrography}

Out of the forty two [42] samples collected from the field, sixteen [16] representative samples were presented for thin section. The slides were prepared at the laboratory of the Department of Geology at the University of Jos, Nigeria. These thin sections which represent the lithological units in the study area were studied under the transmitted light microscope. Particular attention was given to descriptive features such as mineral composition, grain size and inclusions.

The report that follow groups pay particular attention was given to descriptive features as mineral composition, grain size and inclusions. The estimated modal composition of these rocks are given in in form of pie charts.

\subsection{Diorite/gabbroic dolerite}

The diorite and gabbroic diorite look similar in hand specimen. The rock is medium-grained and compose of crystals few millimetres in size. It is dark grey to greenish black in colour. Minerals observed include plagioclase and pyroxenes, others are aphinitic and commonly visible in thin section.

Under the microscope, plagioclase constitute occurs in the groundmass and occasionally as phenocryst that is 1 to $3 \mathrm{~mm}$ long and 0.3 to $1 \mathrm{~mm}$ wide. Extinction angle of plagioclase $\left(35^{\circ}\right)$ indicate the presence of labradorite. It is typically euhedral to subhedral, lath shaped crystal, exhibiting subhedral granular texture. It shows albite and Carlsbad twining. Zoned labradorite grains are present and few are partly altered showing chlorite rims or sericite.

Augite has a less obvious ophitic texture with subhedral grain that is green in colour. Hornblende is brown in colour and is more commonly intergrown with augite. It is anhedral and show low relief. Biotite show pleochroic colour from pale brown to dark brown and is more commonly associated with hornblende, quartz and very often with opaque iron oxide. Quartz occur as rounded to sub rounded interstitial grains up to $1 \mathrm{~mm}$ in diameter between plagioclase grains or their altered products. Common accessories include iron oxide, zircon and ilmenite (Figs. 10, 11 and 12).

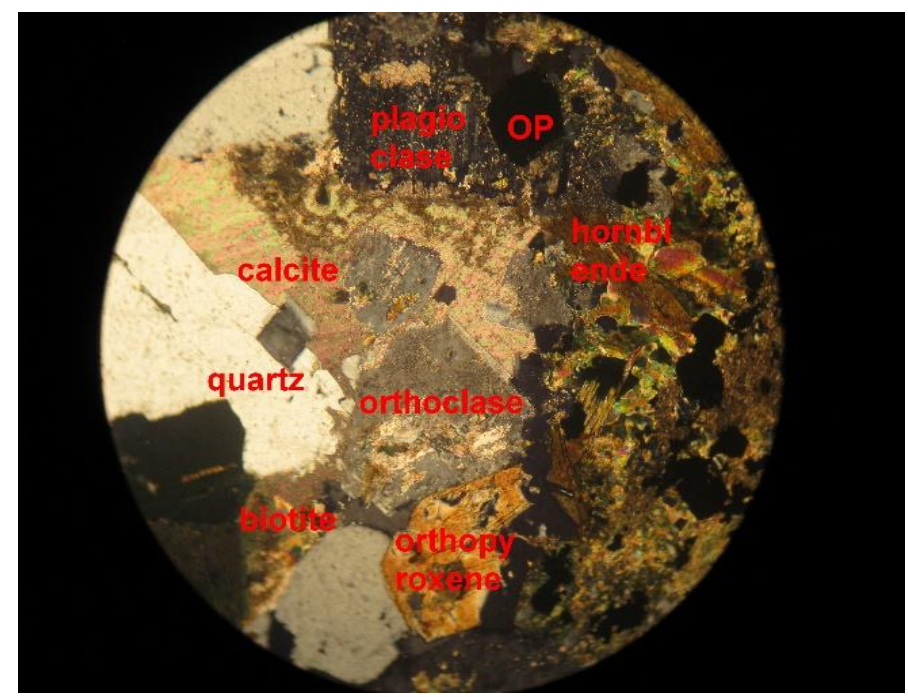

Fig. 10: Photomicrograph of Diorite.

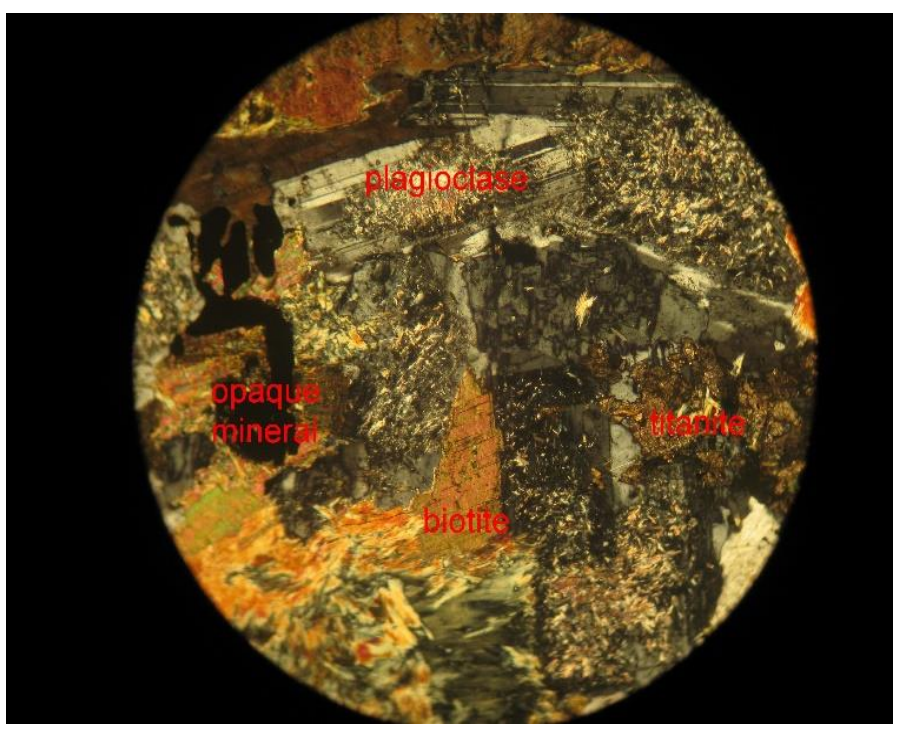

Fig. 11: Photomicrograph of Biotite Granite. 


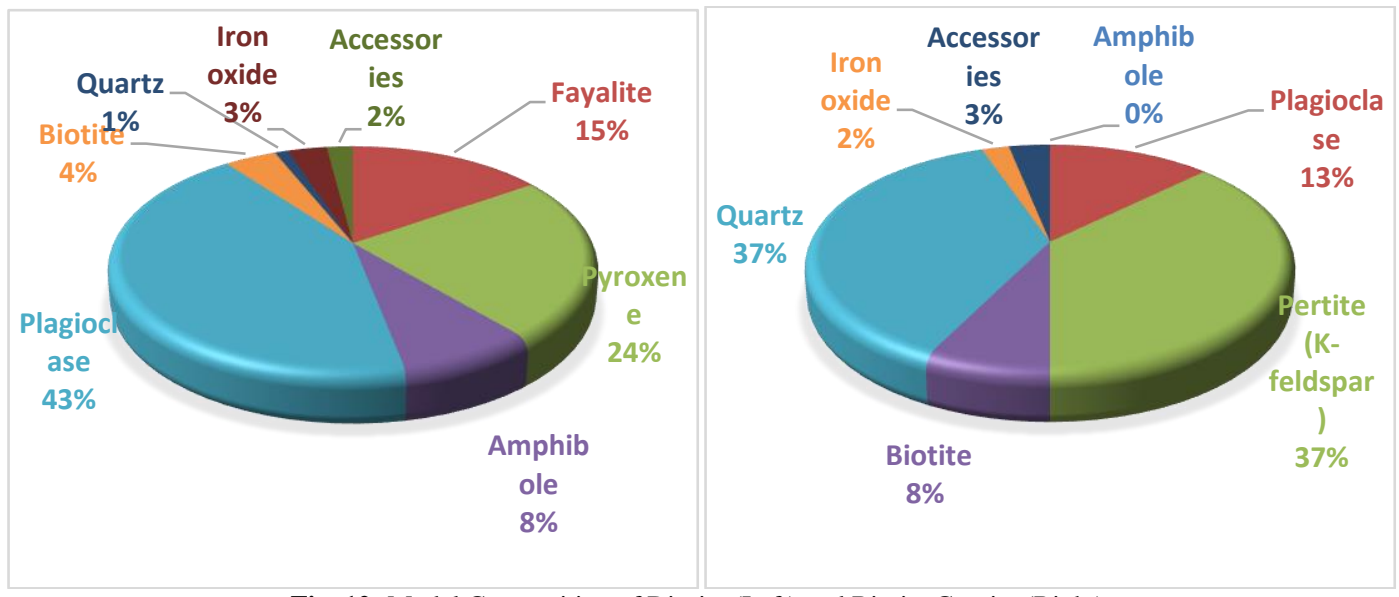

Fig. 12: Modal Composition of Diorite (Left) and Biotite Granite (Right).

\subsection{Biotite granite}

In hand specimen, the rock is fine to medium grained and appears dark brown in colour. Minerals observed include hornblende, biotite,

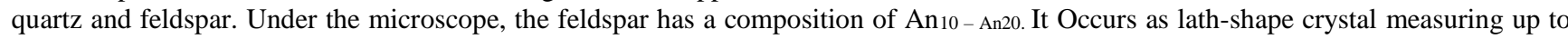
$1 \mathrm{~mm}$ in length and constitute the majority of the groundmass. It also shows both albite and Carlsbad twining and free from inclusions. The main K-feldspar is an orthoclase which appear as anhedral and some patches are cloudy due to alteration. The microcline occurs as interstitial grains or replacement rims around the orthoclase. Quartz is clearly colourless, anhedral and show wavy extinction. Hornblende is the chief mafic constituent and is brown in colour with cleavage in two direction. Biotite is light to dark brown and occur as isolated patches. Where it is clustered, it is accompanied by zircon and iron oxide which are accessory minerals.

\subsection{Biotite microgranite}

In hand specimen, the rock is fine to medium grained and dark brown in colour. Minerals present include quartz, k-feldspar (orthoclase), albite, hornblende and accessory minerals.

Under the microscope, the plagioclase exhibit albite twining and the laths measure up to 0.2 to $0.7 \mathrm{~mm}$ long and 0.1 to $0.5 \mathrm{~mm}$ wide. The lath shape subhedral crystals often display subhedral granular texture in near vicinity of K-feldspar or quartz. The K-feldspars occur with inclusion of globular quartz, some biotite flates and plagioclase. Microcline appear colourless under plane polarized light but exhibits light grey colour under crossed polarized light. Quartz occur as single grain or very often as aggregates. It exhibit undulose or wavy extinction and appear grey to colourless. Hornblende is green in colour and commonly altered to iron oxide. Biotite crystals are anhedral with a perfect one directional cleavage with pleochroic colours from dark brown to pale brown. Accessory minerals include iron oxide and zircon (Fig.13 and Fig. 15a).

\subsection{Quartz-feldspar granite porphyry}

In hand specimen, the rock is coarse grained and light to pink in colour. It has a pitted surface on account of different surface weathering, making the feldspars to stand out profusely.

Under the microscope, hornblende is the chief mafic constituent and is generally greenish and pleochroic from light to dark green. The plagioclase in this rock is albite and is well twinned (albite twining) with subhedral lath shapes. Orthoclase-microperthite occur as phenocrysts of up to $2 \mathrm{~mm}$ long with a later generation of strongly cross hatched microcline perthite. The orthoclase occur as large anhedral and patch grains that appear cloudy due to alteration. Some of the microcline occur as interstitial grains or replacement rims round orthoclase. Biotite crystals are generally brownish and cleaved in one direction and have parallel extinction. The mineral is subhedral and pleochroic from light to dark brown. Quartz occur as anhedral and it is colorless. There is a micrographic inter-growth with orthoclase and its interlocking pieces usually enclose feldspar and biotite. The opaque mineral present in the thin section is magnetite. Accessories include zircon, sphene and apatite. (Fig. 14 and 15b).

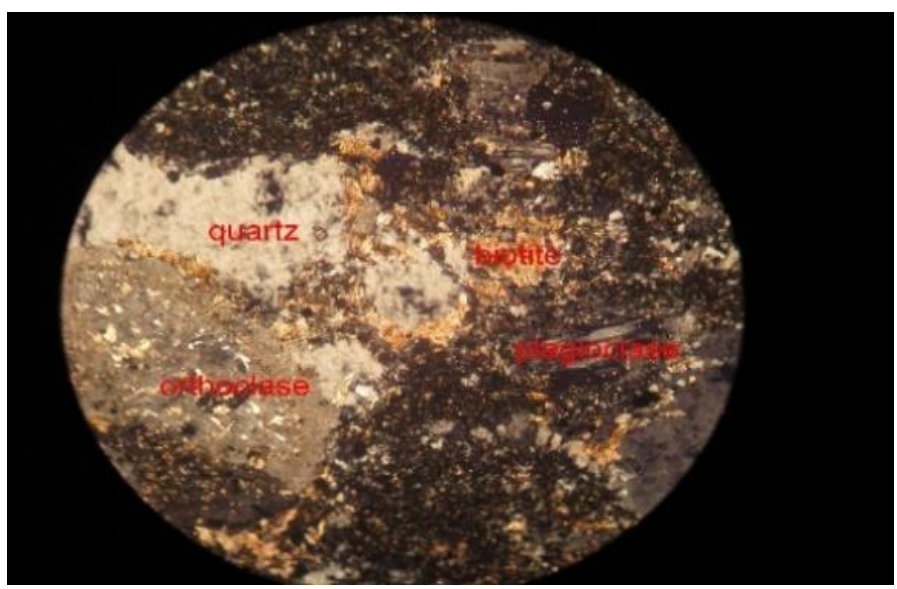

Fig. 13: Slide of Biotite Microgranite. 


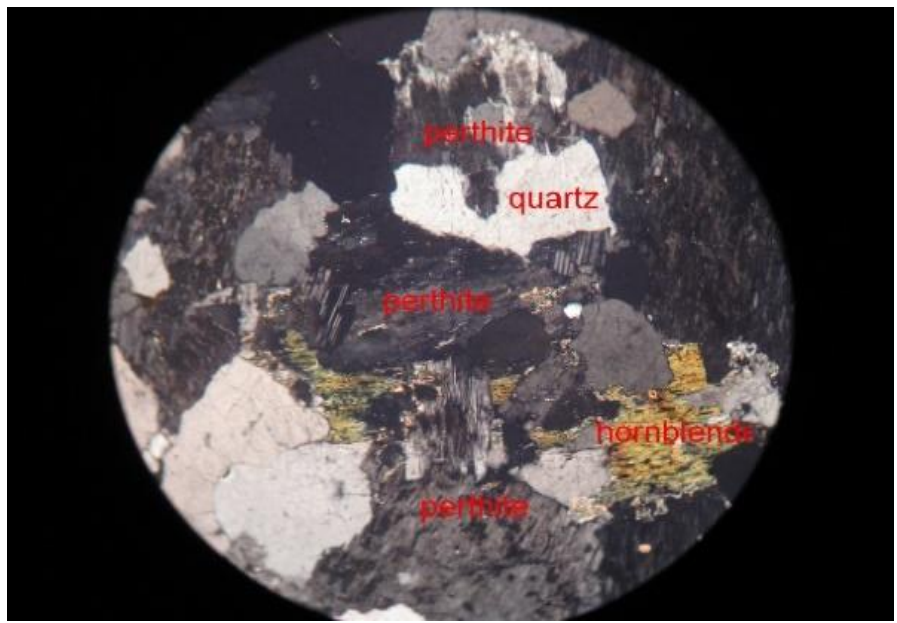

Fig. 14: Slide of Quartz-Feldspar Granite Porphyry.

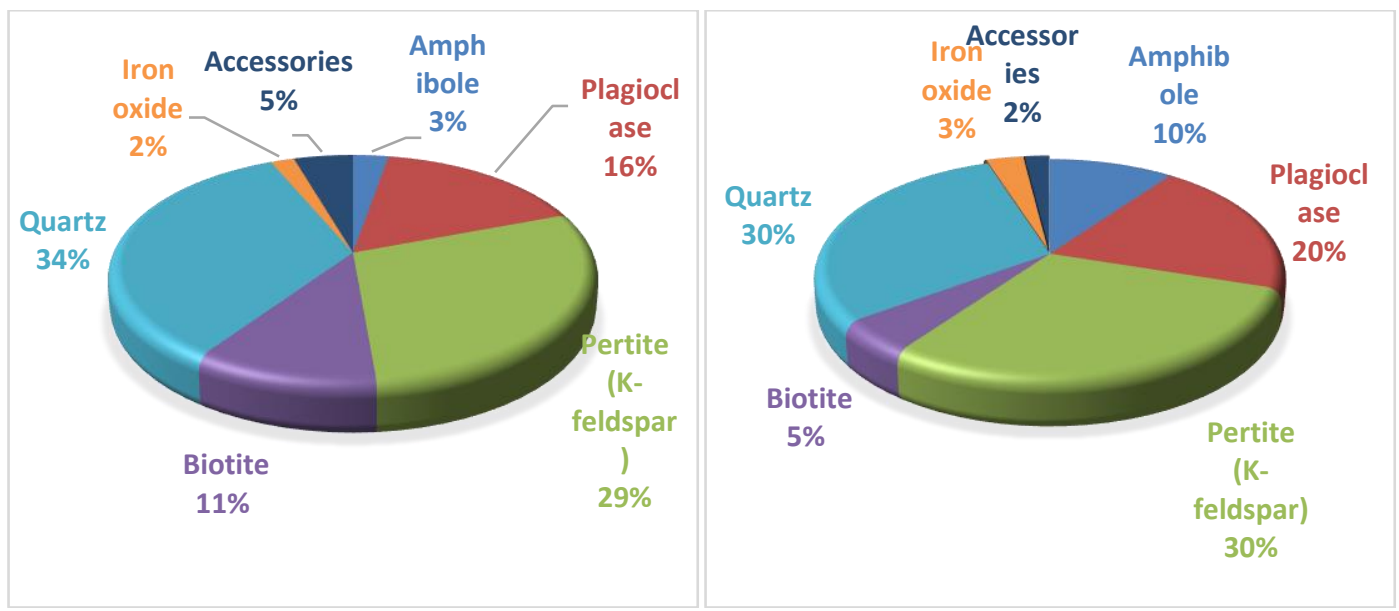

Fig. 15: Modal Composition of Microgranite (Left) and Quartz Granite Porphyry (Right).

\section{Conclusion}

Slides of the mafic rocks which comprise of diorites show that plates of plagioclase and hornblende enclose abundant pyroxene, biotite, olivine and iron oxide. This arrangement usually develop during the crystallization of magma formed from ultramafic rocks like peridotite where plates of hornblende surround grains of divine and pyroxenes forming ophitic texture.

The biotite-microgranite in thin section shows k-feldspar occurring with inclusions of globular quartz. This probably occurred during crystallization or through replacement of one mineral by the other. The slides of diorite examined show biotite and hornblende altering to iron oxide. Probably it was as a result of subsolidus deuteric alteration that was brought about by the felsic injection seen in the hybrid varieties. Generally, the petrography of these rock samples reveal the presence of a mafic magma which has two pulses (a mafic and felsic pulse) of injection.

\section{Acknowledgement}

T. Aga acknowledge the University of Jos for granting him study leave to enable him participate in the geological investigation of the Kofayi Younger Granite Complex. The thin sections were prepared and studied at the laboratory of the Department of Geology at the University of Jos, Jos, Nigeria.

\section{References}

[1] Kinnaird, J.A. (1985): Hydrothermal Alteration and Mineralization of the Alkaline Anorogenic Ring Complex of Nigeria. Journal of African Earth Science. Vol. 3. Pp. 229 - 251. https://doi.org/10.1016/0899-5362(85)90038-7.

[2] Macleod, W.N; Turner, D.C and Wright, E.P. (1971). The Geology of Jos Plateau. Geol.Surv.Nigeria Bull. No.32. Vol.2. 160pp.

[3] Middlemost, E.A. (1985): Magmas and Magmatic Rocks. An Introduction to Igneous Petrology. Longman Group, UK. Pp. $73-87$.

[4] Obaje, N.G. (2009): Geology and Mineral Resources of Nigeria. Springer-Verlag. Berlin. 219pp. https://doi.org/10.1007/978-3-540-92685-6.

[5] Rahaman, M.A. (1988): Recent Advances in the Study of the Precambrian of Nigeria. First Symposium on Precambrian Geology of Nigeria Proceedings, Kaduna. Special Publication of Geological Survey of Nigeria.

[6] Turner, D.C (1989). Structure and Petrology of the Younger Granite Ring Complexes. In C. A. Kogbe (Ed). Geology of Nigeria. Second Revised Edition. Rock View Ltd.Jos. Pp 175-190. 